Docent dr Nebojša Nikolić, potpukovnik, dipl. inž. Institut za strategijska istraživanja, Sektor za politiku odbrane MO

\section{KORISNIČKI ASPEKT PRELAZNOG REŽIMA RADA SISTEMA MASOVNOG OPSLUŽIVANJA}

UDC: $65.012 .122: 355.1$

Rezime:

Problem početnog, prelaznog, nestacionarnog perioda ili perioda zagrevanja postoji niz decenija, kao važan $i$ još uvek aktuelan problem u simulacionom modelovanju sistema masovnog opsluživanja (SMO). Uz primenu jedne teorijske aproksimacije za određivanje dužine prelaznog perioda sugeriše se potencijalni uticaj prelaznog režima na mere performanse sistema. U radu se daje i autorovo viđenje prirode ovog problema, kao i mogući pravac njegovog rešavanja.

Ključne reči: prelazni režim, masovno opsluživanje, simulacija.

\title{
PRACTICAL ASPECTS OF THE TRANSIENT REGIME IN QUEUEING SYSTEMS
}

Summary:

The issue of the initial, transient, non-stationary regime in the queueing system simulation modeling has been an important and still intriguing question for decades. A theoretical aproximation for determining the relaxation time in the queueing process was used to show importance and effects of the transient regime on the measures of queueing system performances. The paper also offers the author's view on the nature of the initial transient regime issue as well as a possible way to tackle it.

Key words: initial transient regime, queueing, simulation.

\section{Uvod}

$\mathrm{Na}$ jednoj renomiranoj konferenciji o simulacijama (Winter Simulation Conference - serija godišnjih američkih konferencija posvećenih simulaciji), održanoj decembra 2005, poznati operacioni istraživač i profesor na Stanford univerzitetu Peter Glin postavio je, pored ostalih, i sledeća pitanja [1]:

1) „U kojim tipovima simulacija početni prelaz i dužina inicijalizacije su često i značajno problematične?

2) Postoji li neka teorijska aproksimacija koja će baciti svetlo na dužinu trajanja početnog prelaza?“
Naučna referentnost, vreme i mesto gde su ova pitanja deklarisana nesumnjivo daje odgovarajući visok nivo značajnosti i aktuelnosti istaknutim pitanjima, čak i u našem vojnoakademskom i vojnonaučnom okruženju. Po logici stvari, to bi trebalo da važi i za potencijalne odgovore na postavljena pitanja. Dobrim poznavaocima simulacionog modelovanja ova pitanja nisu nova. Reč je o problemima koji su prepoznati već u prvim radovima u oblasti simulacionog modelovanja, dakle, poznati su već nekoliko decenija. Pomenućemo samo nekoliko autora radova iz različitih perioda: Gafarian, Anker i Morisaki 1978, [2]; Odoni i 
Rut 1983, [3]; Pawlikovski 1990. i 2002, [4], [5]; Yau 2000, [6] i panel-diskusija [7] renomiranih autora u oblasti simulacionog modelovanja.

Problem početnog prelaza poznat je pod više naziva: početna (inicijalna) faza simulacije; prelazni period; period zagrevanja; nestacionarni period, itd. Do sada je u svetu objavljen veliki broj radova koji tretiraju ovaj problem, pri čemu su predložena i mnoga rešenja, ali je problem ostao aktuelan i u današnje vreme, što na neki način potvrđuju i navedeni upiti profesora Glina.

Svrha ovog rada jeste upoznavanje domaće naučne i stručne javnosti sa fenomenom prelaznog perioda, kao i prikaz potencijalnih odgovora na prethodno navedena pitanja. Za ilustraciju praktičnog značaja prelaznog režima rada sistema masovnog opsluživanja koristiće se jednostavni primer iz oblasti logistike.

\section{Problem početnog prelaza}

$\mathrm{Na}$ osnovu navedenih ali i brojnih drugih radova, može se reći da problem početnog prelaza postoji, pre svega, kod simulacije sistema masovnog opsluživanja (SMO u daljem tekstu). Najčešće razmatrani tip SMO je M/M/n/m/FIFO u Kendalovoj oznaci (videti Vukadinovića, 1988, [11]). U razmatranju problema početnog prelaza obično se razmatra SMO tipa $\mathrm{M} / \mathrm{M} / 1 / \infty$, što je i ovde slučaj. U klasičnom, analitičkom opisu ovaj tip SMO predstavljen je sistemom diferencijalnih jednačina prvog reda [11] sa konstantnim koeficijentima. Argument ili nezavisna promenljiva u ovom sistemu jednačina je vreme, što implicira zaključak o dinamičkom ponašanju SMO, bez obzira na konstantne koeficijente koji predstavljaju konstantne intenzitete tokova klijenta.

Diferencijalne jednačine stanja SMO tipa $\mathrm{M} / \mathrm{M} / \mathrm{n} / \mathrm{m}$ vrlo su jednostavne, a njihov broj direktno zavisi od broja mogućih stanja u kojima se SMO može naći. Poseban slučaj predstavljaju SMO bez posebnog ograničenja broja klijenata u redu, a time i sa neograničenim brojem mogućih stanja sistema. Postupak rešavanja ovog sistema diferencijalnih jednačina stanja SMO, međutim, nije ni malo lak, a rešenja su takve složenosti da su vrlo nepogodna za primenu u praktičnim proračunima. Složenost rešavanja i samih rešenja vrtoglavo raste sa povećanjem broja jednačina stanja SMO. O tome svedoče podaci u tabeli 1 , gde je rešenje za

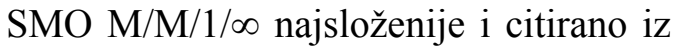
literature (Klajnrok 1975, [8]). U široj literaturi, ova rešenja obično se nazivaju prelazna rešenja ili rešenja za prelazni režim. Međutim, jasno je da su to kompletna rešenja koja važe za bilo koje vrednosti nezavisne promenljive, dakle važe i za prelazni i za stacionarni režim rada.

U prilog značaju razmatranja prelaznog režima navode se reči našeg poznatog profesora Vukadinovića [11], koji kaže: „Sve vreme rada sistema može se podeliti na dva intervala: interval $(0, \mathrm{tp}) \mathrm{i}$ interval $\left(t_{p}, \infty\right)$. Interval vremena $(0, t p)$ naziva se interval prelaznog režima rada sistema, a interval $\left(t_{p}, \infty\right)$ interval stacionarnog režima rada sistema. Veličina $t_{p}$ je momenat kada sistem prelazi iz prelaznog u stacionarni režim rada“. Dalje, na strani 83, Vukadinović konstatuje: „U slučaju kada proces opsluživanja ne traje dugo, potrebno je uzeti u obzir uslov nestacionarnosti. Zato su od posebnog značaja pitanja kada mogu da se koriste rešenja stacionarnog režima rada i ka- 
kva će pri tom biti greška". Pred kraj iste knjige (strana 183), Vukadinović zaključuje: „U dosadašnjim razmatranjima bitno smo uprostili zadatak određivanja verovatnoća različitih stanja, ograničavajući se na stacionarni režim rada, jer svaki sistem opsluživanja dostiže ovaj režim rada posle određenog vremena i pod određenim ograničenjima. U primenama nas, međutim, često interesuje i prelazni period“.
$\mathrm{U}$ vojnim primenama, $\mathrm{u}$ razmatranju sistema i procesa opisivih kao SMO, postoji upravo imperativna potreba za proučavanjem prelaznog perioda. Osnovni razlog za to je prosta činjenica da se mora uvažiti vremenski faktor, pogotovo zbog konačnog trajanja ratova, bojeva, misija i drugih procesa.

Da bi se jednostavno ilustrovala sva složenost izraza iz tabele 1 (pre svega za

Uporedni prikaz teorijskih rešenja za verovatnoće stanja SMO tipa $M / M / 1 / 0, M / M / 1 / 1$ i $M / M / 1 / \infty$

\begin{tabular}{|c|c|c|c|}
\hline $\begin{array}{l}\text { Tip } \\
\text { SMO }\end{array}$ & Jednačine stanja & $\begin{array}{c}\text { Početni i } \\
\text { normirajući } \\
\text { uslovi } \\
\end{array}$ & Rešenja \\
\hline $\mathrm{M} / \mathrm{M} / 1 / 0$ & $\begin{array}{l}\mathrm{p}_{0}(\mathrm{t})=-\lambda \mathrm{p}_{0}(\mathrm{t})+\mu \mathrm{p}_{1}(\mathrm{t}) \\
\mathrm{p}_{1}^{\prime}(\mathrm{t})=\lambda \mathrm{p}_{0}(\mathrm{t})-\mu \mathrm{p}_{1}(\mathrm{t})\end{array}$ & $\begin{array}{l}\mathrm{p}_{0}(0)=1 \\
\mathrm{p}_{1}(0)=0 \\
\sum_{\mathrm{i}=0}^{1} \mathrm{p}_{\mathrm{i}}(\mathrm{t})=1\end{array}$ & $\begin{array}{l}\mathrm{p}_{0}(\mathrm{t})=\frac{1}{1+\rho}+\frac{\rho}{1+\rho} \mathrm{e}^{-(\lambda+\mu) \mathrm{t}} \\
\mathrm{p}_{1}(\mathrm{t})=\frac{\rho}{1+\rho}-\frac{\rho}{1+\rho} \mathrm{e}^{-(\lambda+\mu) t}\end{array}$ \\
\hline $\mathrm{M} / \mathrm{M} / 1 / 1$ & $\begin{array}{l}\mathrm{p}_{0}(\mathrm{t})=-\lambda \mathrm{p}_{0}(\mathrm{t})+\mu \mathrm{p}_{1}(\mathrm{t}) \\
\mathrm{p}_{1}^{\prime}(\mathrm{t})=\lambda \mathrm{p}_{0}(\mathrm{t})-(\lambda+\mu) \\
\mathrm{p}_{1}(\mathrm{t})+\mu \mathrm{p}_{2}(\mathrm{t}) \\
\mathrm{p}_{2}^{\prime}(\mathrm{t})=\lambda \mathrm{p}_{1}(\mathrm{t})-\mu \mathrm{p}_{2}(\mathrm{t})\end{array}$ & $\begin{array}{l}\mathrm{p}_{0}(0)=1 \\
\mathrm{p}_{1}(0)=0 \\
\mathrm{p}_{2}(0)=0 \\
\sum_{\mathrm{i}=0}^{2} \mathrm{p}_{\mathrm{i}}(\mathrm{t})=1\end{array}$ & $\begin{array}{l}\mathrm{p}_{0}(\mathrm{t})=\frac{1}{1+\rho+\rho^{2}}+\frac{\rho}{2(1+\rho+\sqrt{\rho)}} \mathrm{e}^{-(\lambda+\mu+\sqrt{\lambda \mu)} t}+ \\
+\frac{\rho}{2(1+\rho-\sqrt{\rho)}} \mathrm{e}^{-(\lambda+\mu-\sqrt{\lambda \mu) t}} \\
\mathrm{p}_{1}(\mathrm{t})=\frac{\rho}{1+\rho+\rho^{2}}-\frac{\rho(1+\sqrt{\rho)}}{2(1+\rho+\sqrt{\rho)}} \mathrm{e}^{-(\lambda+\mu+\sqrt{\lambda \mu})} \mathrm{t}- \\
-\frac{\rho(1-\sqrt{\rho)}}{2(1+\rho-\sqrt{\rho)}} \mathrm{e}^{-(\lambda+\mu-\sqrt{\lambda \mu)} \mathrm{t}} \\
\mathrm{p}_{2}(\mathrm{t})=\frac{\rho^{2}}{1+\rho+\rho^{2}}+\frac{\rho \sqrt{\rho}}{2(1+\rho+\sqrt{\rho)}} \mathrm{e}^{-(\lambda+\mu+\sqrt{\lambda \mu})} \mathrm{t}- \\
-\frac{\rho \sqrt{\rho}}{2(1+\rho-\sqrt{\rho)}} \mathrm{e}^{-(\lambda+\mu-\sqrt{\lambda \mu)} \mathrm{t}}\end{array}$ \\
\hline$\ldots$ & & $\ldots$ & \\
\hline $\mathrm{M} / \mathrm{M} / 1 / \infty$ & $\begin{array}{l}\mathrm{p}_{0}(\mathrm{t})=-\lambda \mathrm{p}_{0}(\mathrm{t})+\mu \mathrm{p}_{1}(\mathrm{t}) \\
\mathrm{p}_{\mathrm{n}}^{\prime}(\mathrm{t})=\lambda \mathrm{p}_{\mathrm{n}-1}(\mathrm{t})- \\
-(\lambda+\mu) \mathrm{p}_{\mathrm{n}}(\mathrm{t})+\mu \mathrm{p}_{\mathrm{n}+1}(\mathrm{t}) \\
\text { gde je: } \mathrm{n} \geq 1\end{array}$ & $\begin{array}{l}p_{0}(0)=1 \\
p_{n}(0)=0 \\
\sum_{i=0}^{n} p_{i}(t)=1\end{array}$ & $\begin{array}{l}\mathrm{p}_{\mathrm{n}}(\mathrm{t})=\mathrm{e}^{-(\lambda+\mu) t} \\
{\left[\begin{array}{l}\rho^{(\mathrm{n}-\mathrm{i}) / 2} \mathrm{I}_{\mathrm{n}-\mathrm{i}}(\text { at })+\rho^{(\mathrm{n}-\mathrm{i}-1) / 2} \mathrm{I}_{\mathrm{n}+\mathrm{i}+1}(\mathrm{at})+ \\
+(1-\rho) \rho^{\mathrm{n}} \sum_{j=\mathrm{n}+\mathrm{i}+2}^{\infty} \rho^{-j / 2} I_{j}(a t)\end{array}\right]} \\
\text { gde je: } a=2 \mu \rho^{1 / 2} i I_{n}(x)=\sum_{m=0}^{\infty} \frac{(\mathrm{x} / 2)^{\mathrm{n}+2 \mathrm{~m}}}{(\mathrm{n}+\mathrm{m}) ! \mathrm{m} !}, \text { uz: } n=0,1,2,3, \ldots\end{array}$ \\
\hline
\end{tabular}




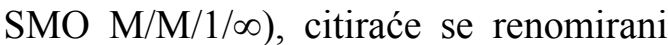
autor Klajnrok, koji je bez ustručavanja i jednostavno opisao ovu situaciju (str. 78) [8]: „Poslednji izraz je veoma razočaravajući. Šta drugo reći kada odgovarajući model za najjednostavniji SMO od interesa vodi do jednog tako komplikovanog izraza za njegove verovatnoće stanja kao vremenski zavisne veličine. Kao posledicu možemo očekivati samo veću složenost i neizglednost u pokušajima da odredimo vremenski zavisno ponašanje SMO opštijih tipova“.

O složenosti ovog izraza svedoče i navodi iz poznate knjige o teoriji masovnog opsluživanja, renomiranih autora Grosa i Harisa, koji kažu sledeće (str. 75) [9]: „Rešavanje $\mathrm{SMO} M / \mathrm{M} / 1 / \infty$ za prelazni režim je komplikovana procedura... Rešenje ovog problema pojavilo se skoro pola veka posle osnovnih radova Erlanga (1909. god.). Prvo poznato rešenje je ono koje su zajedno objavili Lederman i Reuter (1956. god.), u kome su oni koristili spektralnu analizu za opšti proces rađanja i umiranja. Iste godine pojavila su se dva dodatna rada kao rešenje ovog problema, Bailey i Champernonjne (u žurnalu kraljevskog statističkog društva, London, 1956. god.)“.

Tradicionalni pristup u teoriji masovnog opsluživanja podrazumeva razmatranje i proračun sistema diferencijalnih jednačina stanja SMO za uslove stacionarnog režima rada koji, teoretski posmatrano, sigurno nastupa posle beskonačno mnogo vremena, ali uz osnovni uslov da intenzitet dolaznog toka klijenata nije veći od intenziteta opsluživanja. Pri tome se pretpostavlja da je prelazni režim, koji prethodi stacionarnom režimu, relativno kratkotrajan. Mora se naglasiti da je to, ipak, samo pretpostavka; pravi odgovor dale bi samo navedene jednačine.
Uz takvu pretpostavku $(\mathrm{t} \rightarrow \infty)$, koja se implementira već na samom početku, rešavanje sistema diferencijalnih jednačina stanja postaje vrlo jednostavno. Naime, funkcije verovatnoća stanja koje u polaznom sistemu diferencijalnih jednačina jesu u funkciji vremena, posle beskonačno mnogo vremena postaju konstantne. To dalje znači da prvi izvodi funkcija verovatnoća stanja postaju jednaki nuli. Posledica je da polazni sistem diferencijalnih jednačina stanja prelazi u formu sistema algebarskih jednačina, a dalji postupak, kao i sama rešenja, postaje veoma jednostavan (ovaj postupak može se naći u osnovnoj literaturi za teoriju masovnog opsluživanja, kao npr. kod Vukadinovića [11], pa se ovde ne navodi).

$\mathrm{Za}$ razliku od teorijskog tretmana prelaska na razmatranje stacionarnog režima SMO, gde se „potezom pera“ (implementacijom stava: ,t $\rightarrow \infty$ “) stiže u stacionarni režim, u simulaciji SMO „Monte Karlo" to ni izbliza nije tako. Naime, pri simulaciji SMO obično se polazi od logične spoznaje (kada je ona validna, tj. važi za realni sistem koji se modeluje) da je SMO na početku rada prazan, tj. da u njemu nema klijenata. I tada simulacioni model SMO zaista simulira (oponaša) ponašanje SMO, pa polazeći od stanja da na početku rada u SMO nema klijenata, zaista prolazi kroz prelazni režim na svom putu do stacionarnog režima. Statistika za mere performanse SMO koje se prate tada sadrži i podatke svojstvene prelaznom režimu rada. Ako se, ipak, želi statistika pokazatelja rada SMO samo za stacionarni režim, postavlja se pitanje kada on nastupa, odnosno koliki je početni (inicijalni, prelazni, itd.) deo koji treba isključiti iz razmatranja. 
Problem prelaznog režima u simulaciji SMO posebno dolazi do izražaja kada je broj mogućih stanja SMO veliki ili, čak, neograničen. Isto važi i u slučaju visoke opterećenosti servera (,heavy-traffic“), što se čak prikazuje i kao poseban problem u simulaciji SMO, ali i u teorijskim radovima. U tim slučajevima prelazni režim postaje vrlo dug, čak do te mere da je moguće da čitavo vreme funkcionisanja provede $u$ prelaznom režimu i tako uopšte i ne dođe do stacionarnog režima. Otuda se i dobijeni simulacioni rezultati mogu mnogo razlikovati od onih koji su nam dostupni i praktično raspoloživi iz teorije, tj. od rezultata za stacionarni režim. U nizu radova poslednjih decenija problem prelaznog perioda identi- fikovan je kao prepreka obezbeđenju tačnosti simulacionih rezultata. Referenca u odnosu na koju se posmatra pomenuta tačnost jesu teorijske vrednosti posmatranih veličina, ali samo za stacionarni režim rada SMO.

\section{Teorijska aproksimacija dužine početnog prelaza}

Za tip SMO M/M/1/œ, kao jedan od relativno najjednostavnijih, ali i najčešće proučavanih modela, moguće je iskoristiti i neke analitičke rezultate, na primer Morseov [10], ili Grosov i Harisov [9]. Ovi rezultati postoje već veoma dugo i vrlo su jednostavni, pa je neshvatljivo zašto do sada nisu našli širu primenu. Na osnovu rezulta-

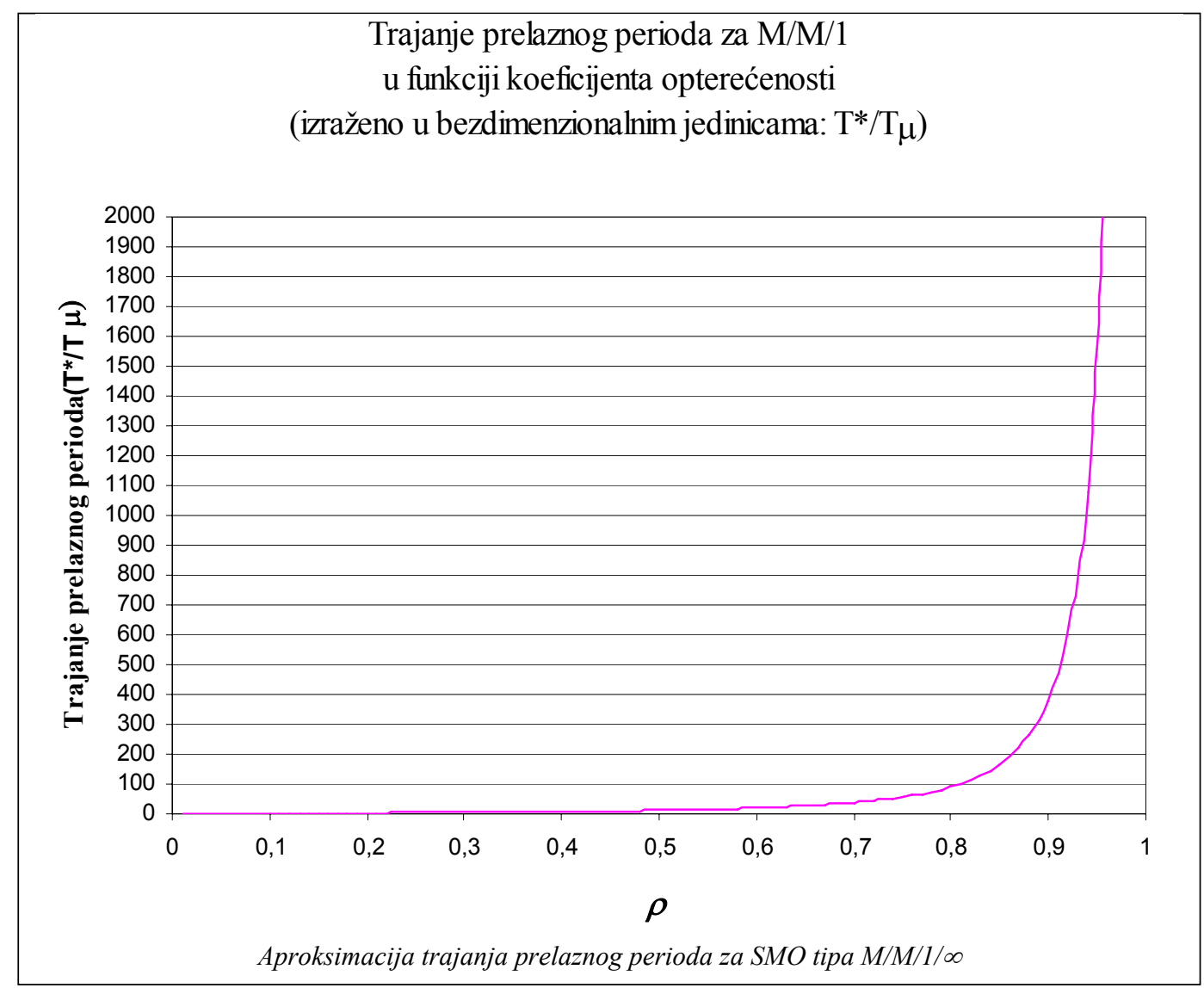


ta Morsea može se izvesti sledeći izraz za određenje dužine prelaznog perioda:

$$
T^{*}=\frac{T_{\mu}}{(1-\sqrt{\rho})^{2}}
$$

gde su:

$\mathrm{T}^{*}$ - vreme relaksacije ( $\mathrm{tj}$. vreme trajanja prelaznog režima, odnosno praktični početak stacionarnog perioda),

$\mathrm{T}_{\mu}$ - prosečno vreme opsluživanja $\left(\mathrm{T}_{\mu}=\right.$ $1 / \mu) \mathrm{i}$

$\rho$ - koeficijent opterećenosti sistema $(\rho=$ $\lambda / \mu)$.

Korišćenjem ove jednostavne formule može se lako odrediti trajanje prelaznog perioda za SMO tipa M/M/1/œ, u funkciji nivoa opterećenosti.

Na slici je prikazano trajanje prelaznog perioda proračunato primenom prethodnog izraza (1), za SMO tipa $\mathrm{M} / \mathrm{M} / 1 / \infty$. Trajanje prelaznog perioda izraženo je u relativnim jedinicama, odnosno preko prosečnog vremena opsluživanja. $\mathrm{Na}$ taj način dobija se univerzalni uvid u trajanje prelaznog perioda, nezavisno o kojim vremenskim jedinicama je reč (milisekunde, sati, dani, itd.) u realnom sistemu tipa $\mathrm{M} / \mathrm{M} / 1 / \infty$.

\section{Korisnički aspekt prelaznog režima}

Pored demonstracija primene izložene teorijske aproksimacije za dužinu prelaznog perioda, u ovom delu članka biće prikazan i korisnički aspekt prelaznog režima rada, odnosno njegov uticaj na mere performanse SMO, prema Nikoliću [17].

$\mathrm{U}$ primeru se razmatra proces evakuacije oštećenih i otkazalih tenkova oklopne brigade u borbenim dejstvima. Za evakuaciju ovih tenkova do mesta gde će se vršiti opravke koristi se vučni voz. Uzima se da je na raspolaganju samo jedan vučni voz (jednokanalni SMO). Radi jednostavnijeg numeričkog proračuna pretpostavlja se da je raspodela vremena između pojave dva zahteva za angažovanjem vučnog voza, radi evakuacije oštećenog tenka, po eksponencijalnoj raspodeli (Poasonov potok klijenata) i da je raspodela vremena evakuacije vučnim vozom, takođe, po eksponencijalnom zakonu. Borbena dejstva koja izvodi ova brigada imaju načelno vreme trajanja angažovanja brigade u boju (5 dana). Razmatraju se tri varijante vrednosti ulaznih podataka, prema tabeli 2 .

Tabela 2

Ulazne vrednosti za zadatak

\begin{tabular}{|c|c|c|c|}
\hline : & $\begin{array}{c}\text { Prosečno vreme između } \\
\text { pojave zahteva za vučni } \\
\operatorname{voz}\left(\mathrm{T}_{\lambda}\right)\end{array}$ & $\begin{array}{l}\text { Prosečno vreme } \\
\text { rada vučnog } \\
\operatorname{voza}\left(\mathrm{T}_{\mu}\right)\end{array}$ & $\begin{array}{l}\text { Koeficijent } \\
\text { opterećenosti } \\
(\rho)\end{array}$ \\
\hline 1. & 240 minuta & 200 minuta & 0,833 \\
\hline 2. & 200 minuta & 190 minuta & 0,95 \\
\hline 3. & 200 minuta & 240 minuta & 1,2 \\
\hline
\end{tabular}

Razmatranjem ovog zadatka treba doći do odgovora na sledeća praktična pitanja koja se mogu, a najčešće se i postavljaju u vojnoj praksi: „Za koliko vremena mogu očekivati da se moj tenk popravi?" (tipično pitanje, ali i sugestivni zahtev komandanta oklopnog bataljona; ovo pitanje može postaviti i komandant ili načelnik štaba ili načelnik OMJ, organu logistike); „Koliko mesta moram da pripremim na SOT-u (sabiralište oštećene tehnike)? Koju dinamiku angažovanja vučnog voza mogu da očekujem?"“ (ko- 
mandir jedinice za održavanje); „Da li je vašoj brigadi zaista potrebna podrška pri evakuaciji oštećenih tenkova, tj. da li vam treba još koji vučni voz i koliko?“" (načelnik TSl korpusa).

Sva ova i druga slična pitanja slivaju se na jedno mesto - kod načelnika tehničke službe brigade. On se smatra najodgovornijim, ali i najkompetentnijim da pronađe tražene odgovore.

Ova relativno jednostavna situacija ima svoju težinu:

- prvo, kanal opsluživanja predstavlja vučni voz; njegova cena je visoka, pa stoga nije racionalno, a nekad ni moguće obezbediti veći broj tih sredstava; takođe, za vučni voz je potrebna i odgovarajuća, dobro obučena posada, što takođe ima svoju cenu;

- drugo, klijenti su oštećeni tenkovi koje treba evakuisati radi opravke; njihova cena je takođe visoka;

- treći, najvažniji aspekt: borbena važnost tenkova je mnogo veća od njihove cene. Izvršenje borbenog zadatka zavisi od operativne gotovosti jedinice, odnosno od broja tenkova „u stroju“. Ako neki od njih bude izbačen iz borbe (ne i uništen) cilj je da se što pre vrati u istu borbu. Za ilustraciju može poslužiti primer bitke za Tobruk, u severnoj Africi, aprila 1941, i odličnog rezultata nemačkih logističkih jedinica: od 100 tenkova izbačenih iz stroja 88 je popravljeno i vraćeno u istu bitku!

- četvrto, i borbena logistička pravila definišu važnost ovog i sličnih zadataka: „obezbediti maksimalni broj, za borbu kritičnih (važnih) sredstava, uz ograničene resurse".

Uobičajeni način rešavanja zadataka ovog tipa podrazumeva primenu rezulta- ta klasične teorije masovnog opsluživanja, uz redovno zanemarivanje činjenice da realni SMO radi konačno vreme (u ovom primeru 5 dana), kao i uz odbacivanje treće varijante zadatka $(\rho>1)$, kao „neprihvatljive“ sa aspekta klasične teorije masovnog opsluživanja. U tabeli 3 prikazani su rezultati (i izrazi po kojima su dobijeni rezultati) uobičajenog načina rešavanja ovakvih zadataka, odnosno određivanje samo rešenja za stacionarni period, za mere performanse koje su najvažnije korisnicima.

Tabela 3

Rezultati primenom klasične teorije masovnog opsluživanja

\begin{tabular}{|c|c|c|c|}
\hline 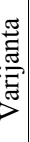 & $\begin{array}{c}\text { Prosečno vreme } \\
\text { čekanja u redu } \\
\mathrm{W}_{\mathrm{lj}}=\mathrm{T}_{\mu} \cdot \rho /(1-\rho)\end{array}$ & $\begin{array}{c}\text { Prosečna dužina } \\
\text { reda } \\
\mathrm{L}_{\mathrm{lj}}=\rho^{2} /(1-\rho)\end{array}$ & $\begin{array}{c}\text { Prosečna } \\
\text { opterećenost kanala } \\
\text { opsluživanja } \\
\rho=\lambda / \mu\end{array}$ \\
\hline 1. & 1000 minuta & 4,17 & 0,833 \\
\hline 2. & 3610 minuta & 18,05 & 0,95 \\
\hline 3. & \multicolumn{2}{|c|}{ Neprimenljivo za $\rho>1$ ! (tj. $\infty$ i $\infty)$} & 1,2 \\
\hline \multicolumn{4}{|c|}{ Sistem masovnog opsluživanja tipa: $\mathrm{M} / \mathrm{M} / 1 / \infty$} \\
\hline
\end{tabular}

Ova uobičajena rešenja sada će, međutim, biti osporena određenim, takođe analitičkim putem, odnosno primenom aproksimativnog analitičkog izraza Morsea, koji sledi u nešto izmenjenoj formi:

$$
\frac{T^{*}}{T_{\mu}}=\frac{1}{(1-\sqrt{\rho})^{2}}
$$

gde su:

$\mathrm{T}^{*}$ - vreme relaksacije ( $\mathrm{tj}$. vreme trajanja prelaznog režima, odnosno praktični početak stacionarnog perioda), 
$\mathrm{T}_{\mu}-$ prosečno vreme opsluživanja $\left(\mathrm{T}_{\mu}\right.$ $=1 / \mu) \mathrm{i}$

$\rho$ - koeficijent opterećenosti sistema $(\rho=$ $\lambda / \mu)$.

Primenom ovog jednostavnog izraza lako se određuju trajanja prelaznog perioda, odnosno praktični početak stacionarnog perioda rada SMO, tabela 4.

Tabela 4

Praktični početak stacionarnog perioda prema teorijskoj aproksimaciji

\begin{tabular}{|c|c|c|c|}
\hline 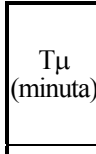 & $\begin{array}{l}\text { Koeficijent } \\
\text { opterećenosti } \\
(\rho)\end{array}$ & 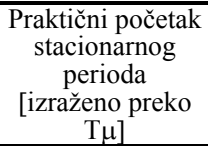 & $\begin{array}{c}\text { Trajanje boja } \\
\text { [izraženo preko } \\
\text { T } \mu: \\
7200 \text { minuta / } \\
\text { T } \mu \text { ] }\end{array}$ \\
\hline 200 & 0,833333 & 132 & 36 \\
\hline 190 & 0,95 & 1560 & 38 \\
\hline 240 & 1,2 & 110 & 30 \\
\hline
\end{tabular}

$\mathrm{Na}$ osnovu rezultata iz tabele 4 , može se zaključiti da posmatrani SMO, za vreme svog angažovanja (pet dana ili 7200 minuta) neće dospeti do praktičnog početka stacionarnog perioda rada SMO pri datim uslovima. Odnosno, za sve vreme angažovanja ovaj SMO radi u režimu karakterističnom za prelazni period (čak je i veoma daleko od stacionarnog perioda). Prema tome, rezultati za mere performanse koji se dobijaju uobičajenom primenom klasične teorije masovnog opsluživanja (tabela 3), a koji važe samo za stacionarni period, nisu validni, tj. ne važe za ovaj zadatak, jer posmatrani SMO za date uslove i vreme rada ne stiže ni blizu stacionarnog perioda.

Logično pitanje koje se ovde može postaviti jeste: ako ti rezultati nisu validni, kako odrediti tačne rezultate, koji nas zanimaju?
Efikasan odgovor moguće je dobiti jedino primenom druge metodologije rešavanja zadatka, odnosno metode simulacionog modelovanja. Međutim, i ovde postoje „uobičajeni“ (poznati, najčešće primenjivani) simulacioni pristupi. Najčešći „uobičajeni“ simulacioni pristup jeste praktična emulacija (kopiranje) onoga što pokriva klasična teorija masovnog opsluživanja, odnosno ravnanje prema rezultatima koji važe samo za stacionarni period. U simulacionom modelovanju SMO postoje, načelno, dva pristupa koji još uvek nemaju naš odgovarajući termin (ali ni jedinstven naziv u svetu, već ima nekoliko termina), pa će biti navedeni u originalu i u slobodnom prevodu:

A) „one simulation run; long simulation run; steady-state simulation; infinite-horizon simulation; non-terminated simulation", odnosno: jedan simulacioni prolaz (jedna simulacija); dugi simulacioni prolaz; simulacija stacionarnog stanja; „neograničena“" simulacija.

B) ,independent replications; replications in parallel; parallel replications; terminating simulation", odnosno: nezavisna ponavljanja (misli se na simulacioni eksperiment); paralelna ponavljanja; terminirajuća (,konačna“) simulacija.

U nastavku slede rezultati primene oba navedena simulaciona pristupa. Svi simulacioni modeli kreirani su korišćenjem simulacionog jezika GPSS/FON, [15]. Cilj prikaza simulacionih rezultata, dobijenih na nekoliko uobičajenih načina simulacionog modelovanja, jeste da se ukaže na njihovu inferiornost $u$ odnosu na simulacione modele kreirane uz primenu inovirane simulacione metode [19]. U daljem rešavanju razmatrana je samo prva varijanta zadatka. 


\section{A) Jedna , duga“ simulacija}

Ovde će biti razmotreno šta se dešava sa simulacionim rezultatima kada se primeni najpopularniji uobičajeni pristup kreiranju simulacionih modela. Reč je o realizaciji jedne „duge“ simulacije. Dužina simulacije može da se izrazi preko broja generisanih klijenata ili preko definisanog vremena trajanja eksperimenta (primenjeno u ovom primeru). Postoji više načina, relativno složenih, za određivanje dužine trajanja simulacije, kao i jedan najjednostavniji, koji je i ovde primenjen. To je proizvoljno i sukcesivno povećavanje trajanja simulacije. U konkretnom primeru razmotrena su tri slučaja: dužina simulacije je povećana najpre 10 puta, zatim 100 puta i na kraju 1000 puta, u odnosu na pravu (verodostojnu) vrednost dužine rada realnog SMO.

Ovaj uobičajeni i popularni simulacioni pristup orijentisan je na dobijanje stacionarnih vrednosti posmatranih mera performansi. Pri tome se kvalitet simulacionih rezultata meri prema tome koliko su oni bliski stacionarnim vrednostima dobijenim na osnovu klasične teorije masovnog opsluživanja (ova provera moguća je samo za jednostavnije SMO, za koje postoje analitička rešenja u teoriji masovnog opsluživanja). Radi toga, simulacioni eksperiment se produžava. $\mathrm{Na}$ taj način, simulacioni model umesto da opisuje realnost (konačno vreme funkcionisanja), teži da emulira nekompletnu teoriju masovnog opsluživanja. Pri tome se narušava, do u potpunosti, jedan od osnovnih principa simulacionog modelovanja: princip verodostojnosti. Jednostavno rečeno, simulacioni model više ne opisuje onaj realni sistem (simuland) zbog kojeg je i stvoren.

U ovom simulacionom pristupu, pored problema dužine trajanja simulacije, postoji još uvek i problem eliminisanja uticaja početne faze simulacije (tj. ,zagrevanje modela“, ,inicijalizacija“, „startovanje simulacije“, itd.). Reč je, u stvari, o uticaju režima rada sistema u prelaznom periodu. Kako je reč o simulacionom pristupu koji praktično ignoriše fenomen prelaznog perioda i nastoji da razmatra rad SMO samo u stacionarnom periodu, onda je jasno da se uticaj prelaznog perioda smatra svojevrsnom smetnjom ili šumom, koji otežava dosezanje tačnijih stacionarnih vrednosti za posmatrane mere performanse.

Sa aspekta ovakvog simulacionog pristupa jasna je potreba: prvo, određivanja dužine trajanja prelaznog perioda (perioda zagrevanja, perioda inicijalizacije, itd.), i drugo, eliminacije njegovog uticaja. I ovaj problem je veoma star i još uvek nema efikasnog rešenja. Postoji više pristupa ovom problemu i svi su manje ili više složeni.

U rešavanju konkretnog zadatka iskoristiće se teorijska aproksimacija Morsea, za određivanje dužine trajanja prelaznog perioda SMO tipa $\mathrm{M} / \mathrm{M} / 1 / \infty$. Na osnovu te teorijske aproksimacije, za konkretni zadatak, za prvu varijantu opterećenja $(\rho=0,8333)$, imamo da je prelazni period dužine $132 \mathrm{~T}_{\mu}$. Prema tome, u simulacionom modelu u početnom periodu dužine $132 \mathrm{~T}_{\mu}$, neće se prikupljati statistički podaci. Nakon tog perioda, saglasno ovom analitičkom rezultatu, trebalo bi da praktično nastupi stacionarni period rada SMO, pa bi, shodno tome, i 
simulacioni rezultati morali da odgovaraju rezultatima klasične teorije. U tabeli 5 prikazani su ovi rezultati, za tri različita trajanja „produžene“ simulacije.

Tabela 5

Rezultati ,jednog dugog simulacionog prolaza“ bez prelaznog režima

\begin{tabular}{|c|c|c|c|c|c|}
\hline \multirow{2}{*}{$\begin{array}{c}\text { Povećanje } \\
\text { dužine si- } \\
\text { mulacije u } \\
\text { odnosu na } \\
\text { pravu } \\
\text { vrednost } \\
\text { (5 dana) }\end{array}$} & \multicolumn{2}{|c|}{$\begin{array}{c}\text { Oznaka } \\
\text { korišćenog } \\
\text { generatora } \\
\text { slučajnih brojeva } \\
\text { (GSB) }\end{array}$} & \multicolumn{3}{|c|}{$\begin{array}{c}\text { Rezultati za stacionarni režim } \\
\text { (uz isključen uticaj prelaznog } \\
\text { perioda u dužini trajanja: } \\
132 \cdot \mathrm{T}_{\mu}=132 \cdot 200 \text { min. }=26400 \\
\text { min.) }\end{array}$} \\
\hline & $\begin{array}{c}\text { za ulazni } \\
\text { tok } \\
\text { klijenata }\end{array}$ & $\begin{array}{c}\text { za izlazni } \\
\text { tok } \\
\text { klijenata }\end{array}$ & $\begin{array}{l}\text { prosečno } \\
\text { vreme } \\
\text { čekanja u } \\
\text { redu } \\
\text { [minuta] }\end{array}$ & $\begin{array}{c}\text { prosečna } \\
\text { dužina reda }\end{array}$ & $\begin{array}{c}\text { prosečna } \\
\text { optereće- } \\
\text { nost } \\
\text { kanala }\end{array}$ \\
\hline $\begin{array}{c}10 \text { puta } \\
\text { (50 dana) }\end{array}$ & 2 & 6 & 456 & 1,86 & 0,727 \\
\hline $\begin{array}{c}100 \text { puta } \\
(500 \\
\text { dana })\end{array}$ & 2 & 6 & 743 & 2,97 & 0,808 \\
\hline $\begin{array}{c}1000 \text { puta } \\
(5000 \\
\text { dana })\end{array}$ & 2 & 6 & 945 & 3,92 & 0,827 \\
\hline \multicolumn{3}{|c|}{$\begin{array}{c}\text { Rezultati na osnovu klasične } \\
\text { TMO }\end{array}$} & 1000 & 4,17 & 0,833 \\
\hline
\end{tabular}

$\mathrm{Na}$ osnovu dobijenih rezultata evidentno je da se: svi simulacioni rezultati međusobno veoma razlikuju; veoma se razlikuju i od rezultata dobijenih klasičnom TMO (rešenja za stacionarni režim), a sa povećanjem dužine trajanja simulacije, sve više se približavaju rezultatima dobijenim na osnovu klasične TMO.

$\mathrm{Na}$ osnovu prethodnog logično se nameću sledeća pitanja: zašto se simulacioni rezultati dosta razlikuju međusobno; zašto se simulacioni rezultati dosta razlikuju od rezultata klasične TMO; zašto se uopšte javljaju razlike ovih rezultata; da li ima neke zakonitosti i kakve u činjenici da se sa produžavanjem simulacionog eksperimenta dobijaju sve bo- lji rezultati; koji rezultati se mogu koristiti kao tačni; kako objasniti toliku različitost rezultata, ako je uticaj prelaznog perioda isključen za sva tri slučaja dužine simulacije?

Potrebno je razmatrati kakvi su simulacioni modeli kreirani, odnosno kakve realne situacije oni predstavljaju. Vreme angažovanja razmatranog realnog SMO je pet dana, a prema tim simulacionim modelima: u prvom slučaju to je 50 dana, u drugom slučaju to je 500 dana, i u trećem slučaju 5000 dana!

Ne samo jedan boj, već i čitavi ratovi, naročito ratovi modernog doba, ne traju toliko dugo. Iz izloženog se na najbolji način vidi sva ograničenost primene uobičajenih simulacionih pristupa, ali takođe i klasične teorije masovnog opsluživanja. Pored očigledne logičnosti, utemeljenje za ovakvu analizu jeste u konceptu verodostojnosti, poznatom u oblasti simulacionog modelovanja, [20].

Dodatno, za drugu varijantu zadatka $(\rho \rightarrow 1)$ bilo bi potrebno još veće produženje simulacionih eksperimenata da bi se dobili rezultati bliski stacionarnim vrednostima; dok treća varijanta $(\rho>1)$ praktično ne bi mogla da se razmatra primenom ove simulacione metode.

\section{B) Nezavisna ponavljanja simulacije}

Sada je primenjen drugi simulacioni pristup, odnosno realizovan je veći broj nezavisnih ponavljanja simulacija. Simulacioni model kreiran je prema rezultatima istraživanja, Nikolić, 2005, [19], odnosno prema metodi automatizovanog ponavljanja simulacionih eksperimenata sa 
prikupljanjem statistike slučajnih procesa. Dobijeni rezultati prikazani su u tabeli 6 .

Rezultati na osnovu nezavisnih ponavljanja simulacija

\begin{tabular}{|c|c|c|c|c|}
\hline \multirow{2}{*}{\multicolumn{2}{|c|}{$\begin{array}{l}\text { Tip SMO: M/M/1/ } \infty \\
\text { Vreme rada SMO: } 5 \text { dana } \\
\text { Dužina simulacije: } 7200 \\
\text { minuta }\end{array}$}} & \multicolumn{2}{|c|}{ Metod rešavanja } & \multirow{2}{*}{$\begin{array}{c}\text { Relativni } \\
\text { odnos } \\
\text { klasičnog } \\
\text { novog } \\
\text { rešenja }\end{array}$} \\
\hline & & $\begin{array}{c}\text { klasična } \\
\text { TMO } \\
\text { (samo } \\
\text { stacionarne } \\
\text { vrednosti) }\end{array}$ & $\begin{array}{c}\text { simulacioni } \\
\text { rezultati } \\
\text { (veličina } \\
\text { uzorka: } \\
100000 \text { ) }\end{array}$ & \\
\hline \multirow{3}{*}{$\begin{array}{c}\text { Varijanta } 1 \\
\left(T_{\mu}=200 \mathrm{~min} .\right. \\
\rho=0,833)\end{array}$} & \begin{tabular}{|l} 
prosečno \\
vreme čekanja \\
[minuta]
\end{tabular} & 1000 & 411 & 2,4 \\
\hline & $\begin{array}{l}\text { prosečna } \\
\text { dužina reda }\end{array}$ & 4,17 & 1,82 & 2,3 \\
\hline & \begin{tabular}{|l|} 
verovatnoća \\
da je kanal \\
slobodan \\
\end{tabular} & 0,17 & 0,27 & 0,6 \\
\hline \multirow{3}{*}{$\begin{array}{c}\text { Varijanta } 2 \\
\left(T_{\mu}=190 \text { min., }\right. \\
\rho=0,95)\end{array}$} & \begin{tabular}{|l} 
prosečno \\
vreme čekanja \\
[minuta] \\
\end{tabular} & 3610 & 526 & 6,9 \\
\hline & $\begin{array}{l}\text { prosečna } \\
\text { dužina reda }\end{array}$ & 18,05 & 2,81 & 6,4 \\
\hline & \begin{tabular}{|l|} 
verovatnoća \\
da je kanal \\
slobodan \\
\end{tabular} & 0,05 & 0,20 & 0,25 \\
\hline \multirow{3}{*}{$\begin{array}{c}\text { Varijanta } 3 \\
\left(T_{\mu}=200 \text { min., }\right. \\
\rho=1,2)\end{array}$} & \begin{tabular}{|l} 
prosečno \\
vreme čekanja \\
[minuta] \\
\end{tabular} & $(\infty)$ & 854 & $(\infty)$ \\
\hline & $\begin{array}{l}\text { prosečna } \\
\text { dužina reda }\end{array}$ & $(\infty)$ & 4,66 & $(\infty)$ \\
\hline & $\begin{array}{l}\text { verovatnoća } \\
\text { da je kanal } \\
\text { slobodan }\end{array}$ & (0) & 0,12 & (0) \\
\hline
\end{tabular}

Dobijeni simulacioni rezultati su veoma različiti u odnosu na rezultate koji se zasnivaju na primeni klasične teorije masovnog opsluživanja. Osnovni uzrok tih razlika je uticaj režima rada SMO u prelaznom periodu. U konkretnom primeru konstatovano je da razmatrani SMO za vreme svog rada (trajanje borbenih dejstava) uopšte i ne stigne do stacionarnog perioda. Ako se ova činjenica previdi ili zanemari, pa se koriste samo rešenja koja nudi klasična TMO (rešenja za stacionarni period), nastupaju grube greške u određivanju vrednosti posmatra- nih mera performansi SMO. Kako se iz ovog primera vidi (tabela 6), te greške mogu biti i višestruke.

Primenom predložene simulacione metode moguće je rešiti i slučajeve preopterećenosti SMO (varijanta tri zadatka). To je od posebnog interesa kod složenijih SMO, odnosno kod mreža redova čekanja, kada se ne može uvek predvideti da li će se slučaj preopterećenja SMO pojaviti. Dobijeni rezultati (tabela 6) u saglasnosti su i sa praktičnim iskustvima, jer za realne SMO često važi: „,naš kanal opsluživanja je veoma opterećen i mi (opslužioci) radimo skoro stalno, ali na čekanju nema toliko mnogo sredstava, niti je čekanje tako veliko, kao što to sugerišu rezultati klasične TMO“.

\section{Zaključak}

Problem početnog prelaza javlja se u simulaciji sistema masovnog opsluživanja koji su percipirani kao dinamički sistemi. Osnovni koncept sistema masovnog opsluživanja: klijenti - red čekanja - kanal opsluživanja, široko je primenljiv, odnosno njime je moguće prikazati veliki broj sistema i procesa iz najrazličitijih oblasti, kako inžinjerskih tako i organizacionih, uključujući i vojne sisteme i procese.

U široj literaturi iz teorije masovnog opsluživanja postoji vrlo jednostavan izraz za analitičku aproksimaciju dužine relaksacionog perioda, odnosno početnog ili prelaznog režima rada sistema masovnog opsluživanja tipa $\mathrm{M} / \mathrm{M} / 1$.

U zadacima iz prakse mogu se naći sistemi i procesi opisivi kao sistemi masovnog opsluživanja koji sve vreme funkcionisanja provode $\mathrm{u}$ prelaznom 
režimu. Najznačajnija praktična posledica prelaznog režima rada jeste uticaj na relevantne mere performanse sistema. Potencijal uticaja prelaznog režima jeste takav da posmatrane mere performanse mogu biti i višestruko različite od tradicionalno računatih vrednosti za stacionarni režim rada. Unapređenom metodom nezavisnih ponavljanja simulacija, moguće je efikasno proučavati problem početnog prelaza i njegovog uticaja.

Literatura:

[1] Glynn, W. P.: Initial transient problem for steady-state output analysis, Proceedings of the 2005 Winter Simulation Conference, December 2005, pp. 739-740.

[2] Gafarian, A. V., Ancker C. J., Morisaku T.: Evaluation of commonly used rules for detecting steady state in computer simulation, Naval Research Logistics, 1978, pp. 511-529.

[3] Odoni, A., Ruth E.: An Emirical Investigation of the Transient Behavior of Stationary Queueing Systems, Operations Research, Vol. 31, No. 3, May-Jun 1983, pp. 432-455.

[4] Pawlikowski, K.: Steady-State Simulation of Queueing Processes: A Survey of Problems and Solutions, ACM Computing Surveys, Vol. 22, No. 2, Jun 1990, pp. 123-171.

[5] Pawlikowski, K., Jeong H. D. J., Ruth Lee J. S.: On credibility of simulation studies of telecommunication networks, IEEE Communications Magazine, January 2002, pp. 132-139.

[6] Yau, V.: An empirical comparison of methodologies for obtaining results with specific accuracy and for run-length control in quantitative simulation, Transactions of the society for computer simulation international, Vol. 17, N2, 2000, pp. 89-101.

[7] Androttir, S. and others, panel, Analysis methodology: are we done?, Proceedings of the 2005 Winter Simulation Conference, December 2005, pp. 790-796.

[8] Kleinrock, L.: Queueing systems, Volume I: Theory, John Wiley \& Sons, New York, 1975.

[9] Gross, D., Harris M. C.: Fundamentals of queueing theory, John Wiley \& Sons, New York, 1974.

[10] Morse, P. M.: Queues, inventories and maintenance, John Wiley \& Sons, New York, 1958.

[11] Vukadinović, S.: Masovno opsluživanje, Naučna knjiga, Beograd, 1988.

[12] Vukadinović, S.: Elementi teorije verovatnoće i matematičke statistike, Privredni pregled, Beograd, 1990.

[13] Mališić, J.: Slučajni procesi, teorija i primene, Građevinska knjiga, Beograd, 1989.

[14] Schriber, T.: Simulation using GPSS, John Wiley \& Sons, New York, 1978.

[15] Radenković, B.: Modelovanje i simulacija organizacionih sistema korišćenjem simulacionog sistema GPSS/FON, FON, Beograd, 1991.

[16] Nikolić, N.: Uticaj parametara boja na tehničko obezbeđenje u oklopnoj brigadi, Magistarski rad, Sektor SONID, VTA, VJ, Beograd, maj 2000.

[17] Nikolic, N.: Limitations of theoretical and commonly used simulation approaches in considering military queueing systems, Proceedings $15^{\text {th }}$ European Simulation Symposium, Delft, Holland, October 2003, pp. 602-607.

[18] Nikolic, N.: Fidelity in studying of military queueing systems, European Simulation Interoperability Workshop ESIW 2004, Edinburgh, UK, July 2004. (www.sisostds.org).

[19] Nikolić, N.: Istraživanje modela i metoda masovnog opsluživanja za primenu u vojnim procesima, doktorska disertacija, Vojna akademija, Beograd, jun 2005.

[20] Defence Modeling and Simulation Office, DoD Modeling and simulation (M\&S) Verification, Validation, and Accreditation (VVA), Recommended practices guide, DMSO, Alexandria, VA, 1997. 
Tabela 1

Uporedni prikaz teorijskih rešenja za verovatnoće stanja SMO tipa $M / M / 1 / 0, M / M / 1 / 1 \quad i \quad M / M / 1 / \infty$

\begin{tabular}{|c|c|c|c|}
\hline $\begin{array}{l}\text { Tip } \\
\text { SMO }\end{array}$ & Jednačine stanja & $\begin{array}{c}\text { Početni i } \\
\text { normi-rajući } \\
\text { uslovi }\end{array}$ & Rešenja \\
\hline $\mathrm{M} / \mathrm{M} / 1 / 0$ & $\begin{array}{l}\mathrm{p}_{0}^{\prime}(\mathrm{t})=-\lambda \mathrm{p}_{0}(\mathrm{t})+\mu \mathrm{p}_{1}(\mathrm{t}) \\
\mathrm{p}_{1}^{\prime}(\mathrm{t})=-\lambda \mathrm{p}_{0}(\mathrm{t})+\mu \mathrm{p}_{1}(\mathrm{t})\end{array}$ & $\begin{array}{l}p_{0}(0)=1 \\
p_{1}(0)=1 \\
\sum_{i=0}^{1} p_{i}(t)=1\end{array}$ & $\begin{array}{l}\mathrm{p}_{0}(\mathrm{t})=\frac{1}{1+\rho}+\frac{\rho}{1+\rho} \mathrm{e}^{-(\lambda+\mu) \mathrm{t}} \\
\mathrm{p}_{1}(\mathrm{t})=\frac{1}{1+\rho}+\frac{\rho}{1+\rho} \mathrm{e}^{-(\lambda+\mu) \mathrm{t}}\end{array}$ \\
\hline $\mathrm{M} / \mathrm{M} / 1 / 1$ & $\begin{array}{l}\mathrm{p}_{0}^{\prime}(\mathrm{t})=-\lambda \mathrm{p}_{0}(\mathrm{t})+\mu \mathrm{p}_{1}(\mathrm{t}) \\
\mathrm{p}_{1}^{\prime}(\mathrm{t})=-\lambda \mathrm{p}_{0}(\mathrm{t})+\mu \mathrm{p}_{1}(\mathrm{t})+ \\
+\mu \mathrm{p}_{2}(\mathrm{t}) \\
\mathrm{p}_{2}^{\prime}(\mathrm{t})=-\lambda \mathrm{p}_{0}(\mathrm{t})+\mu \mathrm{p}_{2}(\mathrm{t})\end{array}$ & $\begin{array}{l}\mathrm{p}_{0}(0)=1 \\
\mathrm{p}_{2}(0)=1 \\
\mathrm{p}_{3}(0)=1 \\
\sum_{\mathrm{i}=0}^{2} \mathrm{p}_{\mathrm{i}}(\mathrm{t})=1\end{array}$ & $\begin{array}{l}\mathrm{p}_{0}(\mathrm{t})=\frac{1}{1+\rho+\rho^{2}}+\frac{\rho}{2(1+\rho+\sqrt{\rho)}} \mathrm{e}^{-(\lambda+\mu+\sqrt{\lambda \mu) t}}+ \\
+\frac{\rho}{2(1+\rho+\sqrt{\rho)}} \mathrm{e}^{-(\lambda+\mu-\sqrt{\lambda \mu) \mathrm{t}}} \\
\mathrm{p}_{1}(\mathrm{t})=\frac{\rho}{1+\rho+\rho^{2}}-\frac{\rho(1+\sqrt{\rho)}}{2(1+\rho+\sqrt{\rho)}} \mathrm{e}^{-(\lambda+\mu+\sqrt{\lambda \mu) \mathrm{t}}}- \\
-\frac{\rho(1+\sqrt{\rho)}}{2(1+\rho-\sqrt{\rho)}} \mathrm{e}^{-(\lambda+\mu-\sqrt{\lambda \mu) t}} \\
\mathrm{p}_{2}(\mathrm{t})=\frac{\rho^{2}}{1+\rho+\rho^{2}}+\frac{\rho \sqrt{\rho}}{2(1+\rho+\sqrt{\rho)}} \mathrm{e}^{-(\lambda+\mu+\sqrt{\lambda \mu) t}}- \\
-\frac{\rho \sqrt{\rho}}{2(1+\rho-\sqrt{\rho)}} \mathrm{e}^{-(\lambda+\mu-\sqrt{\lambda \mu) t}}\end{array}$ \\
\hline$\ldots$ & $\ldots$ & $\ldots$ & $\ldots$ \\
\hline $\mathrm{M} / \mathrm{M} / 1 / \infty$ & $\begin{array}{l}p_{0}^{\prime}(t)=-\lambda p_{0}(t)+\mu p_{1}(t) \\
p_{n}^{\prime}(t)=-\lambda p_{n-1}(t)- \\
-(\lambda+\mu) p_{n}(t)+\mu p_{n+1}(t) \\
\text { gde je: } n \geq 1\end{array}$ & $\begin{array}{l}\mathrm{p}_{0}(0)=1 \\
\mathrm{p}_{\mathrm{n}}(0)=1 \\
\sum_{\mathrm{i}=0}^{\mathrm{n}} \mathrm{p}_{\mathrm{i}}(\mathrm{t})=1\end{array}$ & $\begin{array}{l}\mathrm{p}_{\mathrm{n}}(\mathrm{t})=\mathrm{e}^{-(\lambda+\mu) t} \\
{\left[\begin{array}{l}\left.\rho^{(\mathrm{n}-\mathrm{i}) / 2} \mathrm{I}_{\mathrm{n}-\mathrm{i}}(\mathrm{at})+\rho^{(\mathrm{n}-\mathrm{i}-1) / 2} \mathrm{I}_{\mathrm{n}+\mathrm{i}+1}(\mathrm{at})+\right] \\
+(1-\rho) \rho^{\mathrm{n}} \sum_{j=\mathrm{n}+\mathrm{i}+2}^{\infty} \rho^{-j / 2} I_{j}(a t)\end{array}\right]} \\
\text { gde je: } a=2 \mu \rho^{1 / 2} i I_{n}(\mathrm{x})=\sum_{m=0}^{\infty} \frac{(\mathrm{x} / 2)^{\mathrm{n}+2 \mathrm{~m}}}{(\mathrm{n}+\mathrm{m}) ! \mathrm{m} !}, \text { uz: } n=0,1,2,3, \ldots\end{array}$ \\
\hline
\end{tabular}




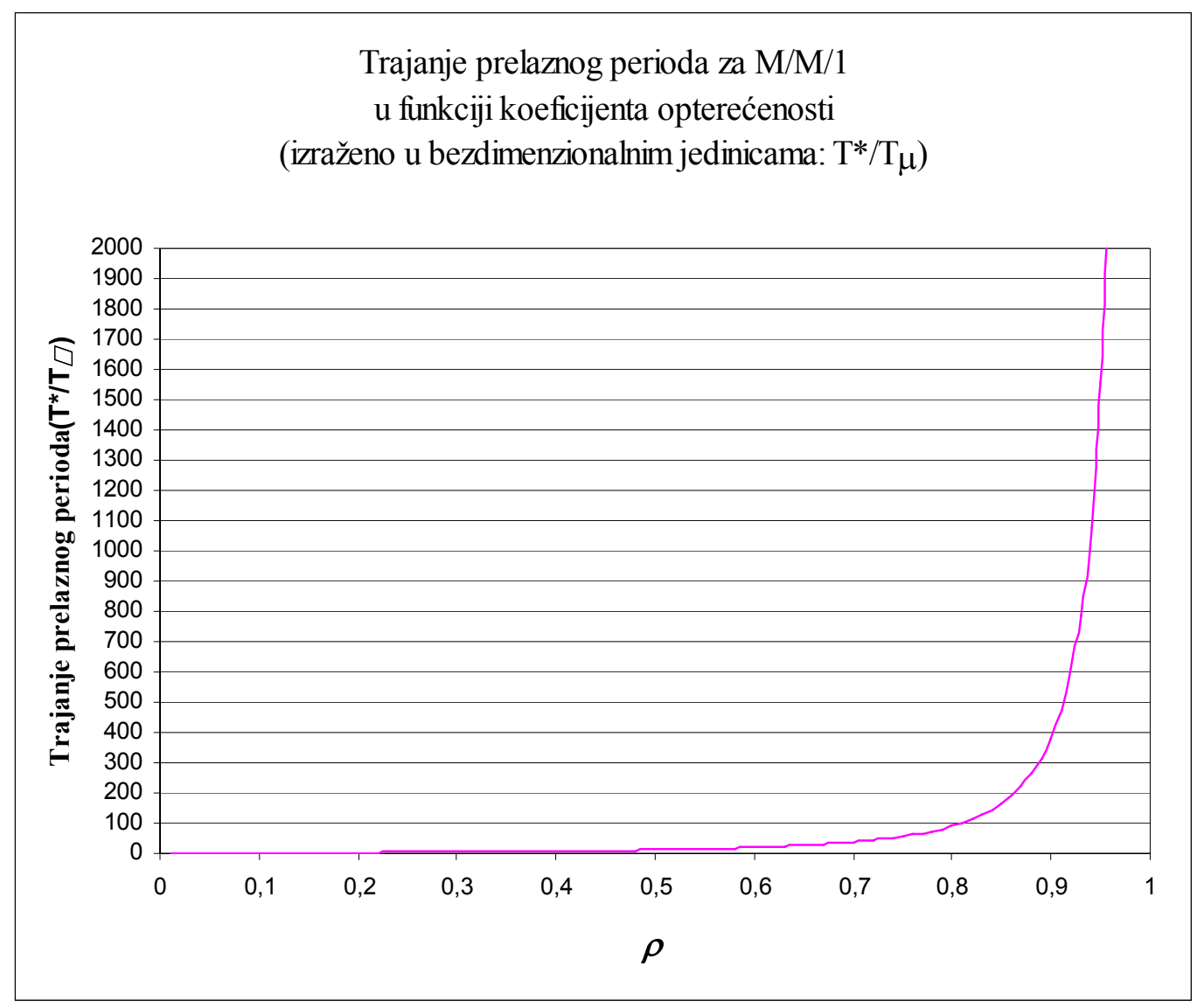

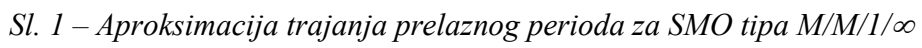

